\title{
TERRACED LANDSCAPES AS PROTECTED CULTURAL HERITAGE SITES
}

Drago Kladnik, Mateja Šmid Hribar, Matjaž Geršič

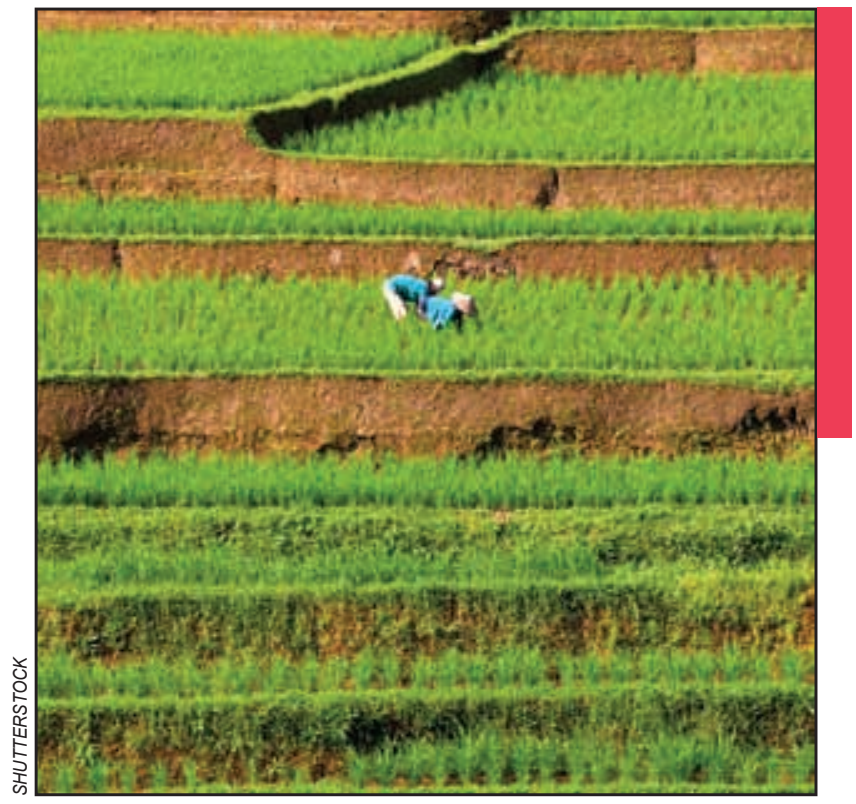

Terraced rice paddies in Bali, a UNESCO world heritage site. 


\section{Terraced landscapes and protected cultural heritage sites}

DOI: http://dx.doi.org/10.3986/AGS. 4628

UDC: $911.53: 631.613(497.4)$

COBISS: 1.01

ABSTRACT: This article presents the current state of protection of terraced landscapes as an important type of cultural landscape, both globally and in Slovenia. The UNESCO World Heritage List, the Satoyama Initiative list, and the Slovenian Register of Immovable Cultural Heritage are analyzed. The findings show that terraces rarely appear as a factor justifying protection, even though certain progress has been made in recent years. At least globally, this has clearly been contributed to by the 2010 adoption of the Honghe Declaration. Slovenia shows both a lack of appropriate criteria for identifying terraced landscapes worth protecting and an insufficiently systematic treatment of heritage sites that are already being protected.

KEY WORDS: geography, cultural landscape, terraces, UNESCO World Heritage, Satoyama Initiative, Slovenian heritage, Slovenia

\section{ADDRESSES:}

Drago Kladnik, Ph.D.

Anton Melik Geographical Institute

Research Center of the Slovenian Academy of Sciences and Arts

Gosposka ulica 13, SI-1000 Ljubljana, Slovenia

E-mail: drago.kladnik@zrc-sazu.si

Mateja Šmid Hribar, Ph.D.

Anton Melik Geographical Institute

Research Center of the Slovenian Academy of Sciences and Arts

Gosposka ulica 13, SI-1000 Ljubljana, Slovenia

E-mail: mateja.smid@zrc-sazu.si

\section{Matjaž Geršič, Ph.D.}

Anton Melik Geographical Institute

Research Center of the Slovenian Academy of Sciences and Arts

Gosposka ulica 13, SI-1000 Ljubljana, Slovenia

E-mail: matjaz.gersic@zrc-sazu.si 


\section{Introduction}

Terraced landscapes are cultural landscapes with a special value, in which their aesthetic role is of great importance in addition to ecological, cultural, historical, research, psychological, philosophical, and religious aspects (Kladnik 2016a; Smrekar, Polajnar Horvat and Erhartič 2016). Therefore, it is not surprising that terraced landscapes are among the world's most picturesque landscapes found online (e.g., Amazing satellite ... 2016; Incredible ... 2014; Tremendous ... 2011). They form a special agricultural and ecological system that can be found throughout the world. They are formed by diverse agricultural terraces, the main purpose of which is to produce food. However, if they are well maintained, they can have an added value in fighting erosion and the negative effects of natural disasters (Komac and Zorn 2008) and in case of extensively management they also ensure biodiversity (Špulerová et al. 2017). However, if terraces are not maintained, this only exacerbates the effects of natural degradation. Unfortunately, due to the restructuring of social strata, maladaptation to mechanized farming, and increasingly pronounced globalization effects, in many places terraces are being abandoned, overgrown, or left to deteriorate in large numbers, while traditional terraced landscapes are becoming neglected (Kladnik 2016a).

Only well-maintained terraced landscapes can present an attractive image that not only makes the locals that live with terraces from one generation to the next proud, but can also prove to be an important part of cultural heritage with developmental potential (Kladnik 2016b). This is true both globally and in Slovenia, and accordingly the awareness that terraced landscapes are worth protecting as an invaluable part of cultural landscapes is gradually strengthening (Erhartič 2009). Various protective initiatives and strategies (Ažman Momirski and Kladnik 2015) have sprung up, which in and of themselves do not automatically guarantee appropriate further maintenance and conservation of terraced landscapes, but they do clearly play an important role in the perception, awareness, discovery, and evaluation of these landscapes. If protection is well thought out and the values of terraced landscapes are suitably promoted, the protection itself can provide an exceptional developmental impulse (Geršič et al. 2016). Together with their increased profile, this makes possible not only further maintenance of an attractive cultural landscape, but also generates new jobs in activities related to the growing number of incoming tourists (Ažman Momirski and Kladnik 2015).

Terraced landscapes belong to cultural landscapes that are the result of the interaction between the natural environment and human life and work in this environment (Urbanc 2002). The expression »cultural landscape « was introduced by the American geographer Carl Sauer, who defined it as follows: »The cultural landscape is fashioned out of the natural landscape by a culture group. Culture is the agent, the natural area is the medium, the cultural landscape is the result " (Sauer 1925, 46). Cultural landscapes are already indirectly mentioned in the 1972 UNESCO Convention Concerning the Protection of the World Cultural and Natural Heritage (Convention ... 1972), which defines cultural heritage as monuments, groups of buildings and sites, which are works of man or the combined works of nature and man, and natural heritage as natural features, geological and physiographical formations and natural sites.

Cultural landscapes that have been internationally recognized and protected since 1992 (Cultural landscapes 2016) are characterized by unique land use adapted to natural conditions and an intangible relationship with nature. An important step towards the recognition of cultural landscapes was made through the 2000 adoption of the European Landscape Convention, which highlights the interaction between natural and human factors, but does not specifically mention terraced landscapes. In the Slovenian legal system, the landscape is mentioned in the Nature Conservation Act (2010), which in principle defines the landscape as a natural value (even though not even a single unit like this can be found in the Register of Natural Values), and in the Cultural Heritage Protection Act (2016), which also covers the Register of Immovable Cultural Heritage (Register ... 2016), in which cultural landscapes are included.

Landscapes are also discussed in the 2010 Paris Declaration on the Satoyama Initiative, which covers socio-ecological production landscapes and seascapes. It conceives of landscapes as »dynamic mosaics of habitats and land uses that have been shaped over the years by the interactions between people and nature in ways that maintain biodiversity and provide humans with goods and services needed for their well-being " (Paris declaration on ... 2010, article 1). Satoyama is a Japanese compound term referring to the area between the foothills of a mountain and arable flat land (< sato »arable, fertile« + yama »mountain, hill«). In the broader sense, satoyama landscapes are a mix of forests, paddy fields, plowed fields, pastures, creeks, ponds, and irrigation systems surrounding Japanese villages (Kobori and Primack 2003). 
As an exceptional landscape system, terraced landscapes were globally recognized at the conference on terraced landscapes that took place in Mengzi, China, in November 2010 and where the Honghe Declaration on the Protection and Development of Terraces was adopted (Peters and Junchao 2012; Kladnik 2016a). That was also when the International Terraced Landscapes Alliance (ITLA) was established (Ažman Momirski and Kladnik 2015).

To date, no comprehensive systematic study on the protection and conservation of terraced landscapes as important cultural landscapes and hence cultural heritage deserving protection has been conducted either globally or in Slovenia. The best-known protected terraced landscapes are mentioned in the works of Tarolli, Preti, and Romano (2014), Varotto (2015), Peters (2015) and Andlar, Šrajer in Trojanović (2017) provided a systematic overview on typological diversity of the Croatian Adriatic terraced landscapes

This article provides an overview of the current state of protection of the terraced landscapes included on the UNESCO World Heritage List (World Heritage List 2016) and in the international database of Satoyama landscapes (Satoyama Initiative 2016) and the Slovenian Register of Immovable Cultural Heritage (Register ... 2016) in one place, drawing attention to the structural deficiencies of the registers and seeking to further enhance efforts for more planned and systematic protection of terraced landscapes.

\section{Methods}

This study is based on a review of two international lists-the UNESCO World Heritage List (2016) and especially its list of cultural landscapes (Cultural Landscapes 2016), and the Satoyama Initiative list (2016)-and the Slovenian Register of Immovable Cultural Heritage (Register ... 2016). Based on the justifications for inclusion on the list and the explanations of the reasons for protection, we identified heritage units (unambiguously or by making inferences based on knowing the actual conditions) that have been selected as worth protecting due to the important role of agricultural terraces. In this, the role of terraced landscapes can be a decisive factor or quite marginal.

Based on the extent of highlighting the significance of terraced landscapes or their role in the justifications for addition to the list, three types were defined at the global level (predominant, highlighted, and marginal) and four among the Slovenian cultural heritage sites (predominant, highlighted, marginal, indirectly identified).

Even though the criteria for classifying terraced landscapes under individual types are subjective, they are based on the comparison of published justifications. They are illustrated here with four sites from the Register of Immovable Cultural Heritage (2016), which we classified under various types. For a better comparison, all of the units are from the same Slovenian region: the mesoregion of the Koper Hills (Sln. Koprska brda).

The predominant type (Register ... 2016):

Puče settlement: the cultivated terraces between Krkavče Creek (Krkavški potok) and Supot Creek (Supotski potok):»The preserved traditional system of cultivated terraces was created where the plateau-like level ridges gradually change into the steep slopes above the Dragonja Valley. The villages of Krkavče and Koštabona dominate the wider area."

The highlighted type:

Seča: the Seča Peninsula cultural landscape: »An area transformed by man for agricultural use, with cultivated terraces and walls built from local stone; dispersed construction, the Forma viva open air sculpture gallery on the promontory. Olive trees, grapevines, and orchards predominate among the cultivars."

The marginal type:

Strunjan: Strunjan Nature Park: "The area south of Strunjan Cliff (Strunjanski klif) features a church with a monastery, dispersed tenant farmers' houses on a slope that has been converted into terraces, a settlement next to the former town harbor, saltpans, and a stone pine avenue."

The indirectly identified type:

Čentur: "A special feature of this village is its characteristic architecture, the special structure of its parcels, and the unique way in which its farmland is cultivated. Arable land is divided into small parcels that extend outwards in concentric circles in order to adjust to the terrain." 


\section{Levels of protection around the globe and in Slovenia}

This section presents the findings of the review of the UNESCO World Heritage List (2016), the Satoyama Initiative (2016) database, and the Slovenian Register of Immovable Cultural Heritage (Register ... 2016).

\subsection{UNESCO World Heritage List}

The UNESCO classification uses the following three categories of cultural landscapes (Operational Guidelines ... 2012):

- Cultural landscape designed and created intentionally by man;

- Organically evolved landscapes, developed as "results from an initial social, economic, administrative, and/or religious imperative and has developed its present form by association with and in response to its natural environment «; divided into two subtypes: a) a relict/fossil landscape and b) a continuing landscape "which retains an active social role in contemporary society closely associated with the traditional way of life, and in which the evolutionary process is still in progress «; and

- Associative cultural landscape.

Figure 1 presents the UNESCO typology of immovable cultural heritage (The World Heritage ... 2004). However, because it is not universal, it is not generally established and applied in individual national legislations.

In June 2016, there were $8.5 \%$ of cultural landscapes among the 1,031 world heritage sites on the UNESCO World Heritage List (Cultural Landscapes 2016). Four of these are listed as transboundary properties, and a German one was removed in 2009 because it did not meet the protection criteria. Twenty are connected with terraced landscapes. Among the rest of the world heritage sites, five are relevant from the viewpoint of terraces. Four are classified under cultural sites and one, the Historic Sanctuary of Machu Picchu, is classified under mixed sites.

Thus we identified a total of 25 relevant terraced landscapes on the UNESCO list (Figure 2): in eight cases, they became part of world heritage almost exclusively due to their terraced character, whereby cultivated terraces are highlighted as their component part, and in nine cases they are mentioned marginally because they were ascribed a high level of protection primarily due to other landscape elements. The majority of the protected sites include a central area measuring several hundred square kilometers (with exceptions over $1,000 \mathrm{~km}^{2}$ ) and a similarly large or smaller buffer zone.

The analysis of 1,641 world heritage sites included on the tentative list (Tentative Lists 2016) showed that only four partly referred also to terraced landscapes (one in France, one in Algeria, and two in Yemen).

The first site that mentions a terraced landscape in the justification, the Natural and CulturoHistorical Region of Kotor, Montenegro, was entered on the UNESCO list as early as 1979 and the second, the Historic Sanctuary of Machu Picchu, Peru, was added to the list in 1983. The first site that refers explicitly to a cultural landscape and a terraced landscape as part of it was the Rice Terraces of the Philippine Cordilleras, which was added to the list in 1995. The graph in Figure 3 shows that the number of these types of world heritage sites is gradually increasing and, what is even more evident, the significance of terraces in the justifications is increasingly more highlighted.

\subsection{Satoyama Initiative}

An important international register of cultural landscapes is being compiled as part of the International Partnership for the Satoyama Initiative (IPSI), which promotes societies in harmony with nature. As part of the Satoyama Initiative, an internet-based portal was established, which among other information provides well-presented case studies of socio-ecological production landscapes around the globe (Satoyama Initiative 2016).

Currently more than 80 case studies are presented in the database, including seven terraced landscapes. The significance of terraces is predominant in three, highlighted in two, and marginal in two. All of the entries on the Satoyama Initiative list are of a more recent date, from 2010 onwards. Two sites, both part of the Ifugao terraced landscape on the Philippine island of Luzon, are included on the UNESCO World 


\begin{tabular}{|c|c|c|c|}
\hline & Monuments & $\begin{array}{l}\text { Groups of } \\
\text { buildings }\end{array}$ & Places \\
\hline $\begin{array}{l}\text { Archaeological } \\
\text { heritage: }\end{array}$ & $\begin{array}{l}\text { Individual monuments, } \\
\text { including earthworks, } \\
\text { farms, villas, temples, } \\
\text { and other public } \\
\text { buildings, defensive } \\
\text { works, etc., that are not } \\
\text { in use or occupied }\end{array}$ & $\begin{array}{l}\text { Settlements } \\
\text { (towns, villages), } \\
\text { defensive works, } \\
\text { etc., that are not in } \\
\text { use or occupied }\end{array}$ & $\begin{array}{l}\text { Earthworks, burial } \\
\text { mounds, cave } \\
\text { dwellings, defensive } \\
\text { works, cemeteries, } \\
\text { routes, etc., that are not } \\
\text { in use or occupied }\end{array}$ \\
\hline Rock-art sites: & - & - & $\begin{array}{l}\text { Caves, rock shelters, } \\
\text { open surfaces, and } \\
\text { comparable sites } \\
\text { containing paintings, } \\
\text { engravings, carvings, etc. }\end{array}$ \\
\hline $\begin{array}{l}\text { Fossil hominid } \\
\text { sites: }\end{array}$ & - & - & $\begin{array}{l}\text { Individual sites and } \\
\text { landscapes containing } \\
\text { skeletal material and/or } \\
\text { evidence of occupation } \\
\text { by early hominids }\end{array}$ \\
\hline $\begin{array}{l}\text { Historic } \\
\text { buildings } \\
\text { and ensembles: }\end{array}$ & $\begin{array}{l}\text { Individual monuments, } \\
\text { ensembles of } \\
\text { monuments, works of art }\end{array}$ & - & - \\
\hline $\begin{array}{l}\text { Urban } \\
\text { and rural } \\
\text { settlements / } \\
\text { historic towns } \\
\text { and villages: }\end{array}$ & - & $\begin{array}{l}\text { Towns, town } \\
\text { centers, villages, } \\
\text { and other } \\
\text { communal groups } \\
\text { of dwellings }\end{array}$ & - \\
\hline $\begin{array}{l}\text { Vernacular } \\
\text { architecture: }\end{array}$ & $\begin{array}{l}\text { Traditionally established } \\
\text { building types using } \\
\text { traditional construction } \\
\text { systems and crafts }\end{array}$ & $\begin{array}{l}\text { Groups of } \\
\text { traditionally } \\
\text { established } \\
\text { building types }\end{array}$ & $\begin{array}{l}\text { Cultural landscapes } \\
\text { with vernacular } \\
\text { settlements }\end{array}$ \\
\hline $\begin{array}{l}\text { Religious } \\
\text { properties: }\end{array}$ & $\begin{array}{l}\text { Buildings and structures } \\
\text { associated with religious } \\
\text { or spiritual values; } \\
\text { e.g., churches, monasteries, } \\
\text { shrines, sanctuaries, } \\
\text { mosques, synagogues, } \\
\text { temples, etc. }\end{array}$ & $\begin{array}{l}\text { Historic } \\
\text { settlements } \\
\text { or towns with } \\
\text { religious } \\
\text { or spiritual } \\
\text { associations: } \\
\text { sacred cities, etc. }\end{array}$ & $\begin{array}{l}\text { Sites with religious } \\
\text { or spiritual associations: } \\
\text { sanctuaries, sacred } \\
\text { landscapes, or landscapes } \\
\text { with sacred features, etc. }\end{array}$ \\
\hline $\begin{array}{l}\text { Agricultural, } \\
\text { industrial and } \\
\text { technological } \\
\text { properties: }\end{array}$ & $\begin{array}{l}\text { Factories; bridges, } \\
\text { water-management } \\
\text { systems (dams, } \\
\text { irrigation, etc.) }\end{array}$ & $\begin{array}{l}\text { Agricultural } \\
\text { settlements; } \\
\text { industrial } \\
\text { settlements }\end{array}$ & $\begin{array}{l}\text { Field systems, } \\
\text { vineyards, agricultural } \\
\text { landscapes; water } \\
\text { management systems } \\
\text { (dams, irrigation, etc.); } \\
\text { mines, mining } \\
\text { landscapes, canals, } \\
\text { railways, etc. }\end{array}$ \\
\hline $\begin{array}{l}\text { Military } \\
\text { properties: }\end{array}$ & Castles, forts, citadels, etc. & $\begin{array}{l}\text { Citadels, town } \\
\text { defenses; }\end{array}$ & Defensive systems \\
\hline
\end{tabular}

Figure 1: UNESCO typology of immovable cultural heritage (The World Heritage ... 2004, 15). Green cells contain material related to cultural landscapes. 


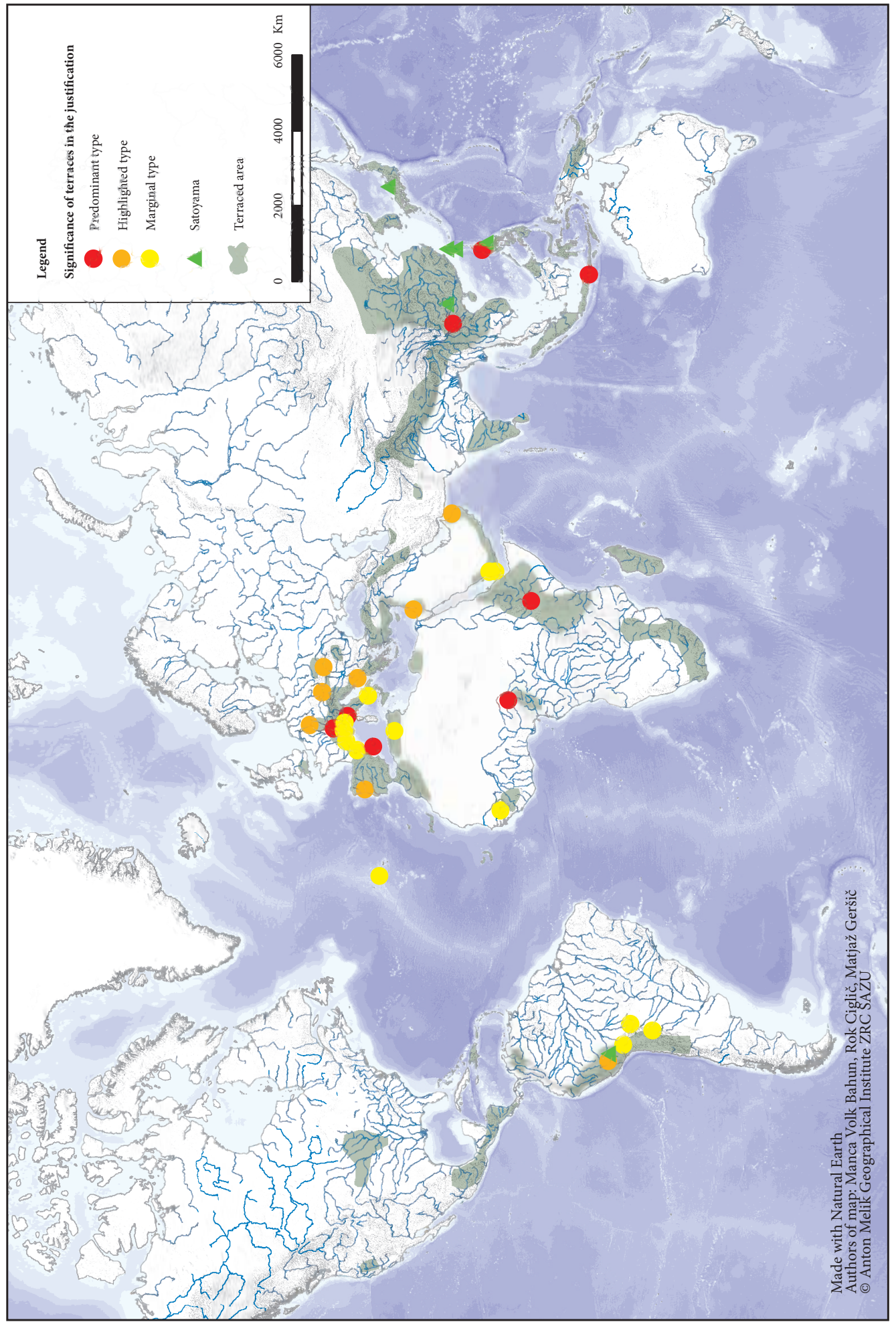


Drago Kladnik, Mateja Šmid Hribar, Matjaž Geršič, Terraced landscapes and protected cultural heritage sites

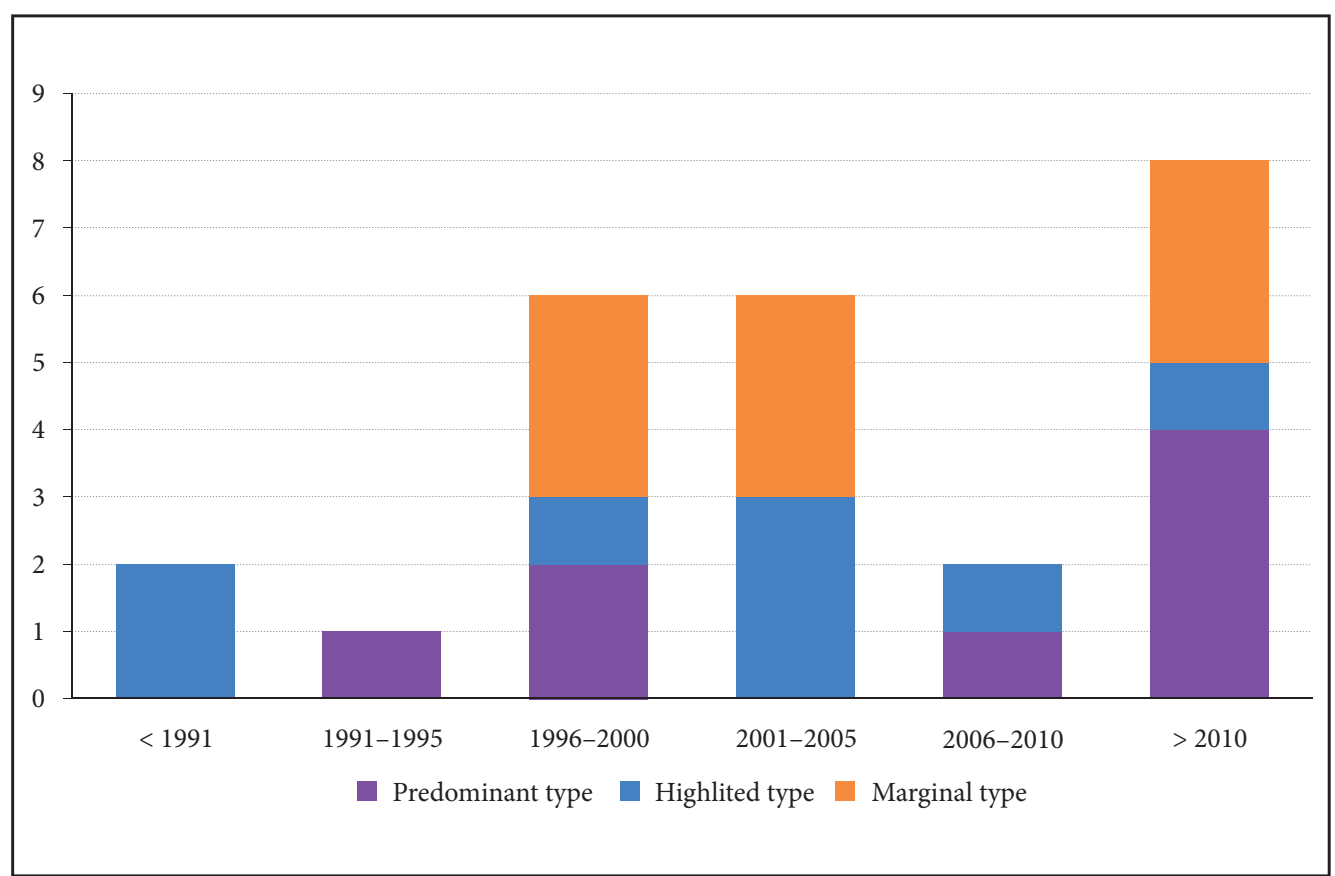

Figure 3: The period in which the terraced landscapes identified were entered on the UNESCO World Heritage List (2016) according to the significance of terraces in the justifications for entry on the list.

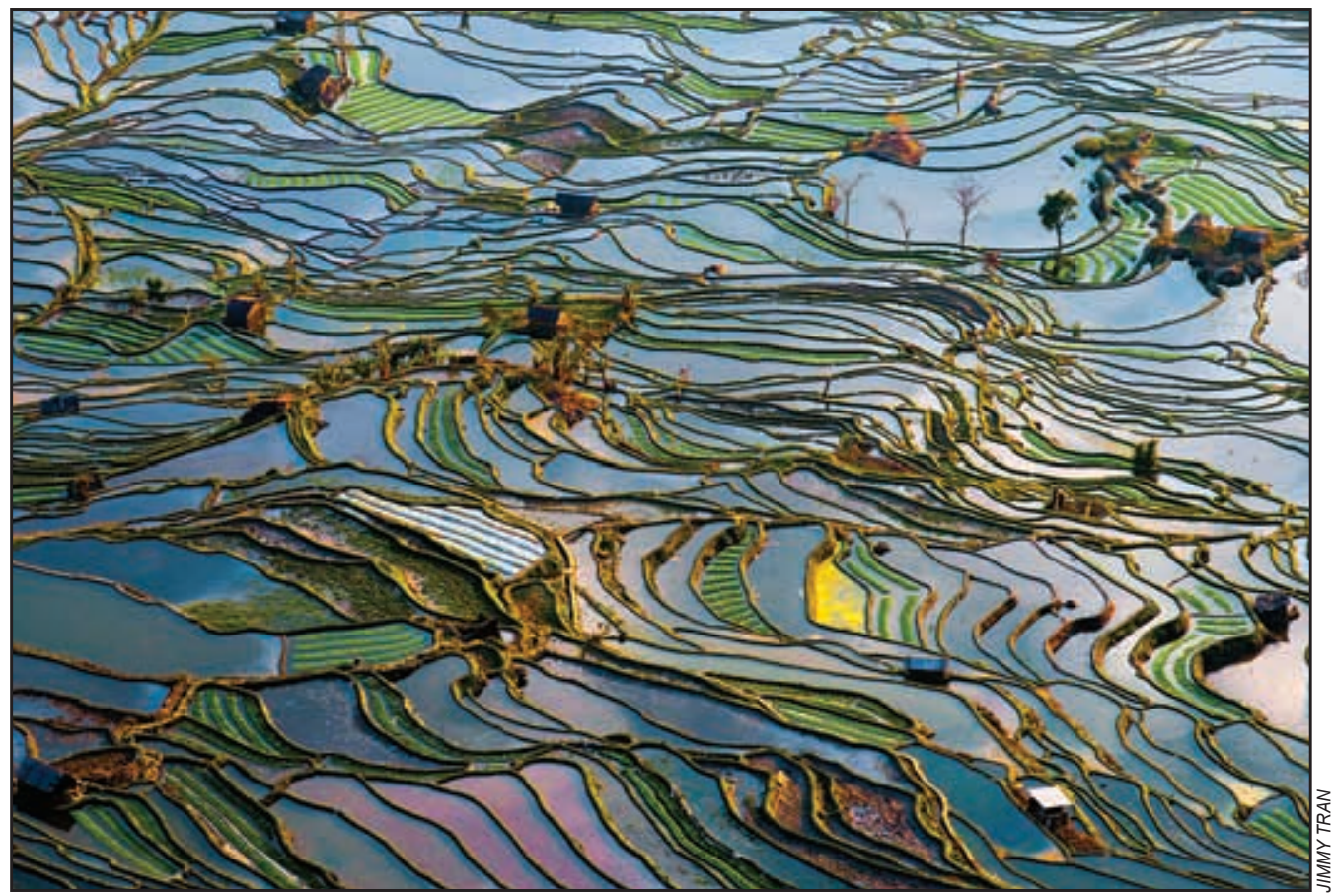

Figure 4: The cultural landscape of the Honghe Hani Rice Terraces in China. 


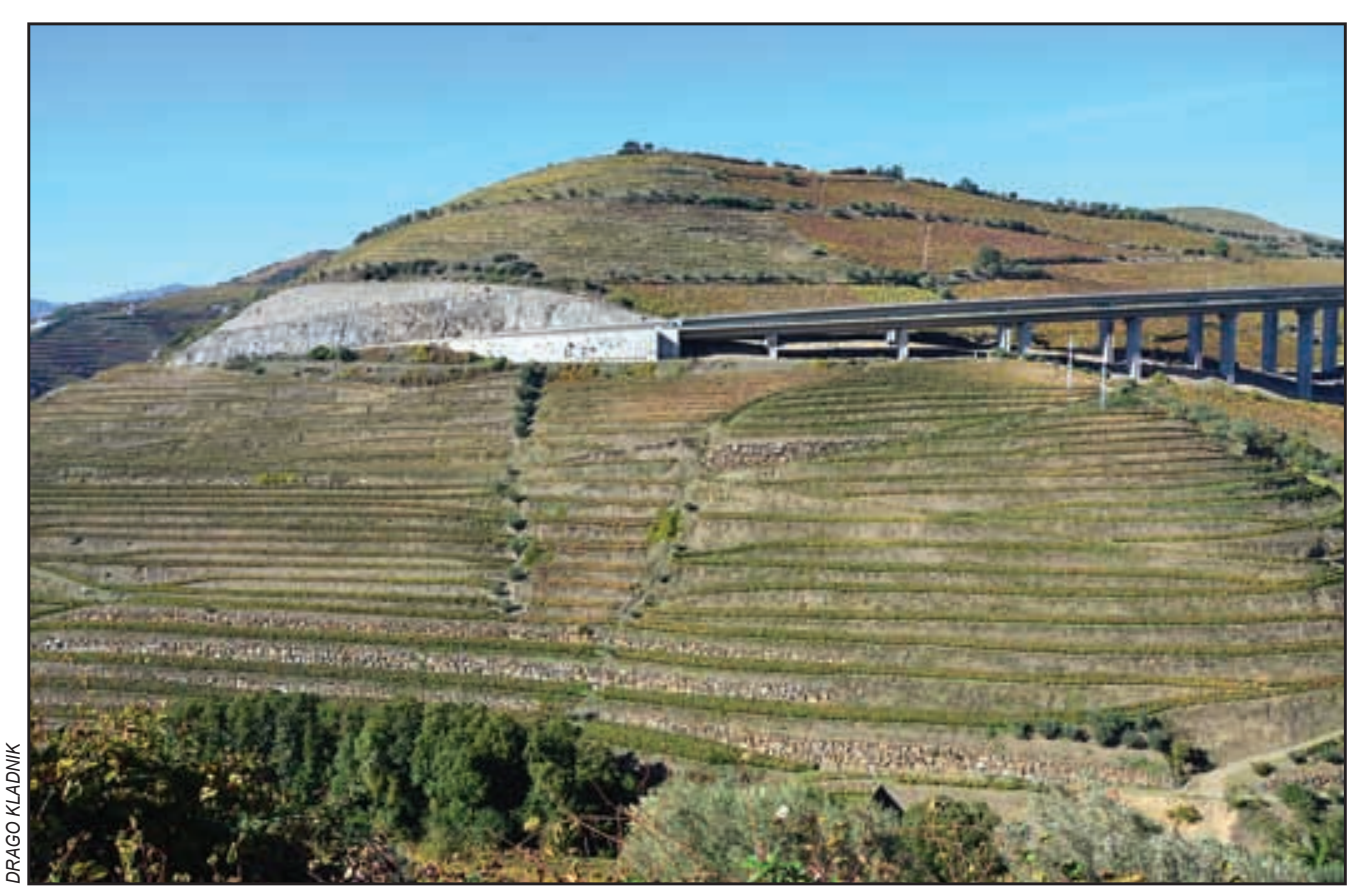

Figure 5: The terraced landscape of the Upper Douro (Alto Douro) Wine Region in Portugal.

Heritage List. All of the sites on the UNESCO World Heritage List and the Satoyama Initiative list are presented in Figure 6.

\subsection{Slovenian Register of Immovable Cultural Heritage}

In Slovenia, the protection of terraced landscapes is provided for as part of the Cultural Ministry's Register of Immovable Cultural Heritage (Register nepremične kulturne dedǐ̌čine) (Register ... 2016), which also includes cultural landscapes among the eight defined types of heritage and two non-defined types (unknown and other). In June 2016, the register included 317 sites, among which forty-three terraced landscapes can be identified (Figure 7, Table 1). In two cases, terraces were the decisive reason for addition to the register, in seventeen cases they were a very important reason, in twelve cases they were not mentioned at all because other reasons were more important for the entry, and in twelve cases agricultural terraces were not mentioned but they can be inferred from the descriptions.

Among the total of 50 mesoregions, only 18 include protected terraced landscapes. By far the greatest number of registered terraced cultural landscape sites can be found in the Koper Hills (10) and the Sava Hills (8). Among the nine landscape types, they can be found in six, but not on the Mediterranean plateaus and in the Alpine mountains, where terraced landscapes do not exist anyway.

Figure 6: Terraced landscapes as identified in 2016 on the UNESCO World Heritage List (2016), UNESCO Tentative Lists (2016), and Satoyama Initiative (2016). The names of sites fully recognized by UNESCO are given in plain text, sites on the UNESCO Tentative Lists in italics, and sites on the Satoyama Initiative list in underlined italics. $>$ p. 138

Figure 7: Terraced landscapes identified in the Slovenian Register of Immovable Cultural Heritage (Register .. 2016). > p. 139 
Drago Kladnik, Mateja Šmid Hribar, Matjaž Geršič, Terraced landscapes and protected cultural heritage sites

\begin{tabular}{|c|c|c|c|c|c|c|}
\hline 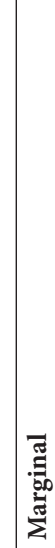 & 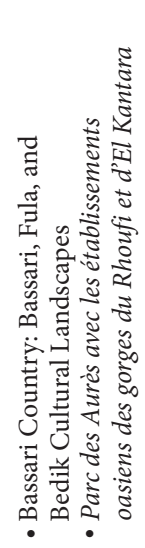 & 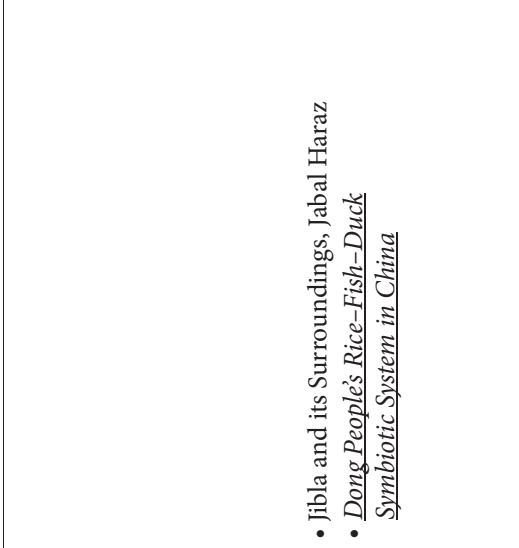 & 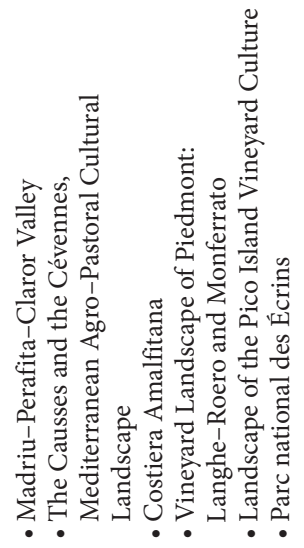 & & 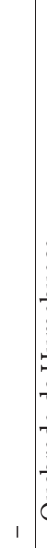 & 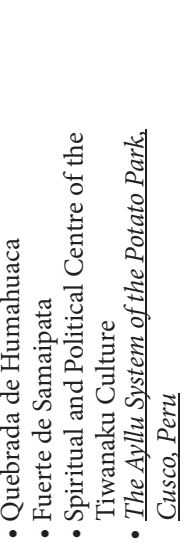 \\
\hline 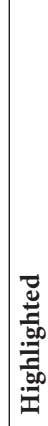 & 1 & 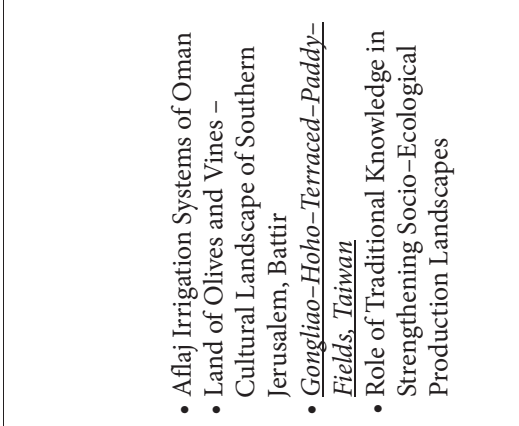 & 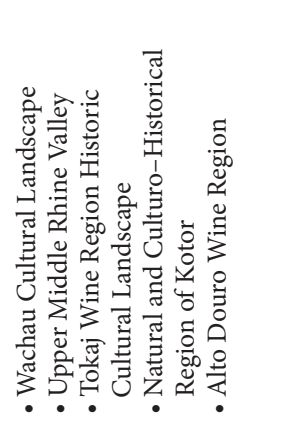 & & 1 & 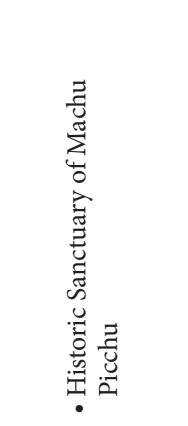 \\
\hline 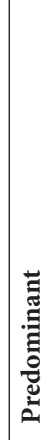 & 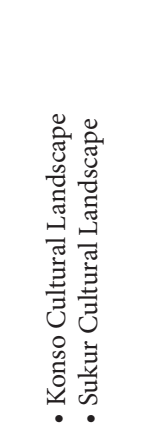 & 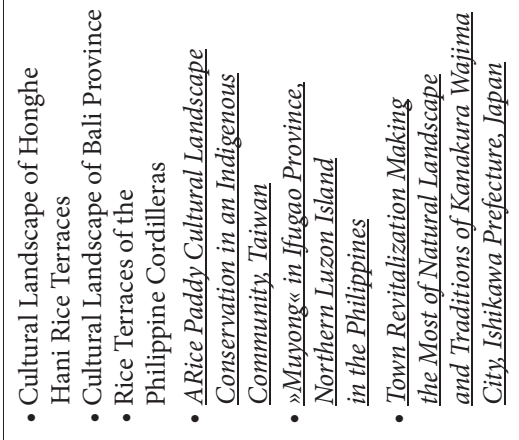 & 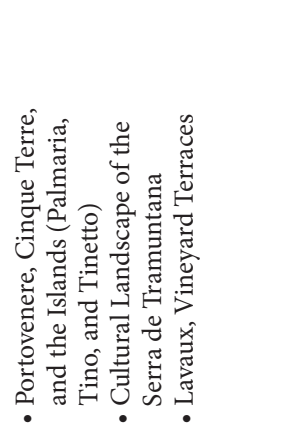 & & 1 & 1 \\
\hline ن & 焉 & $\frac{5}{4}$ & 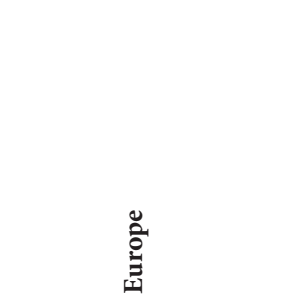 & 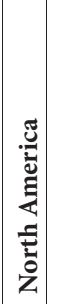 & 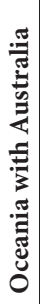 & 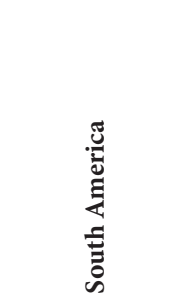 \\
\hline
\end{tabular}




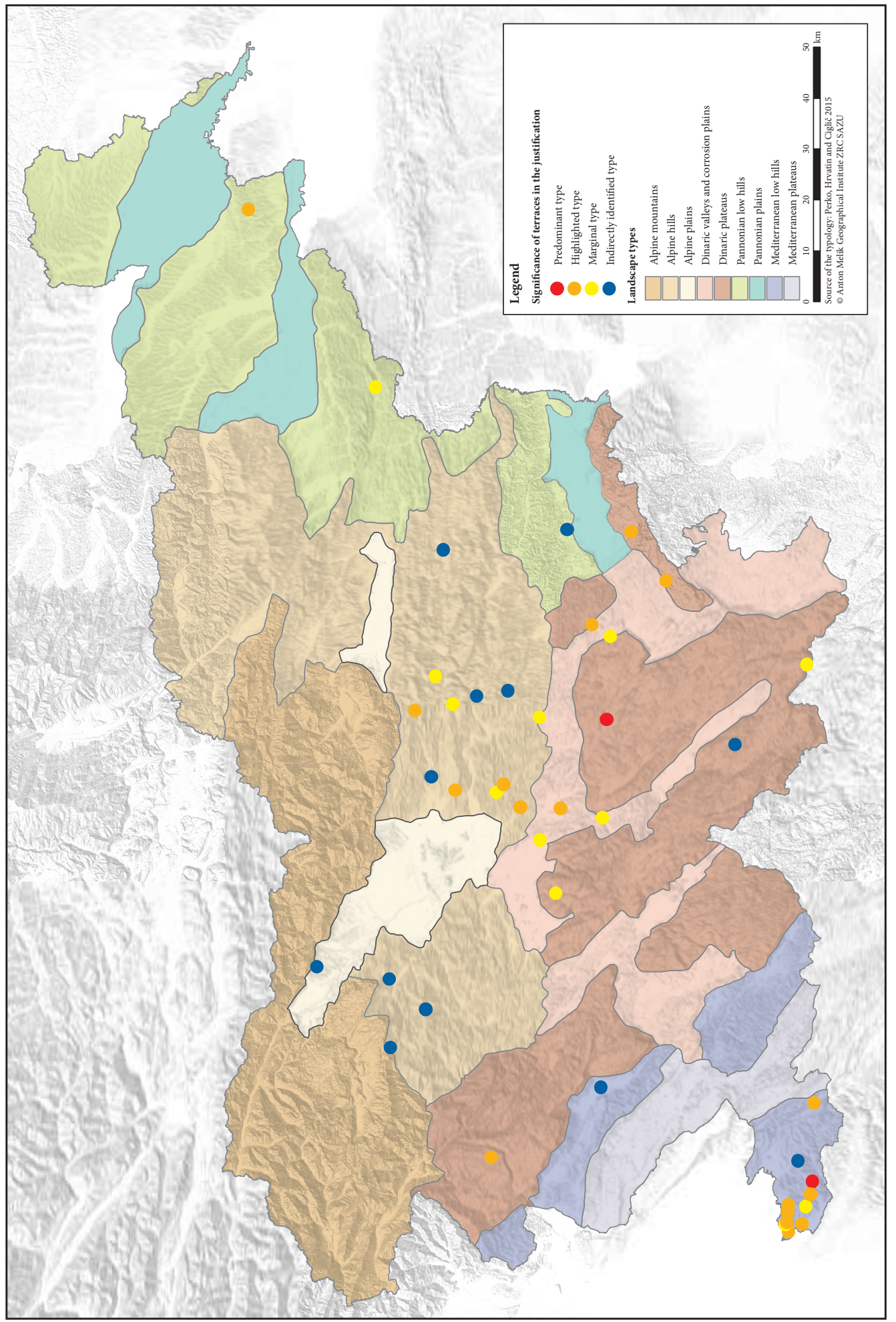




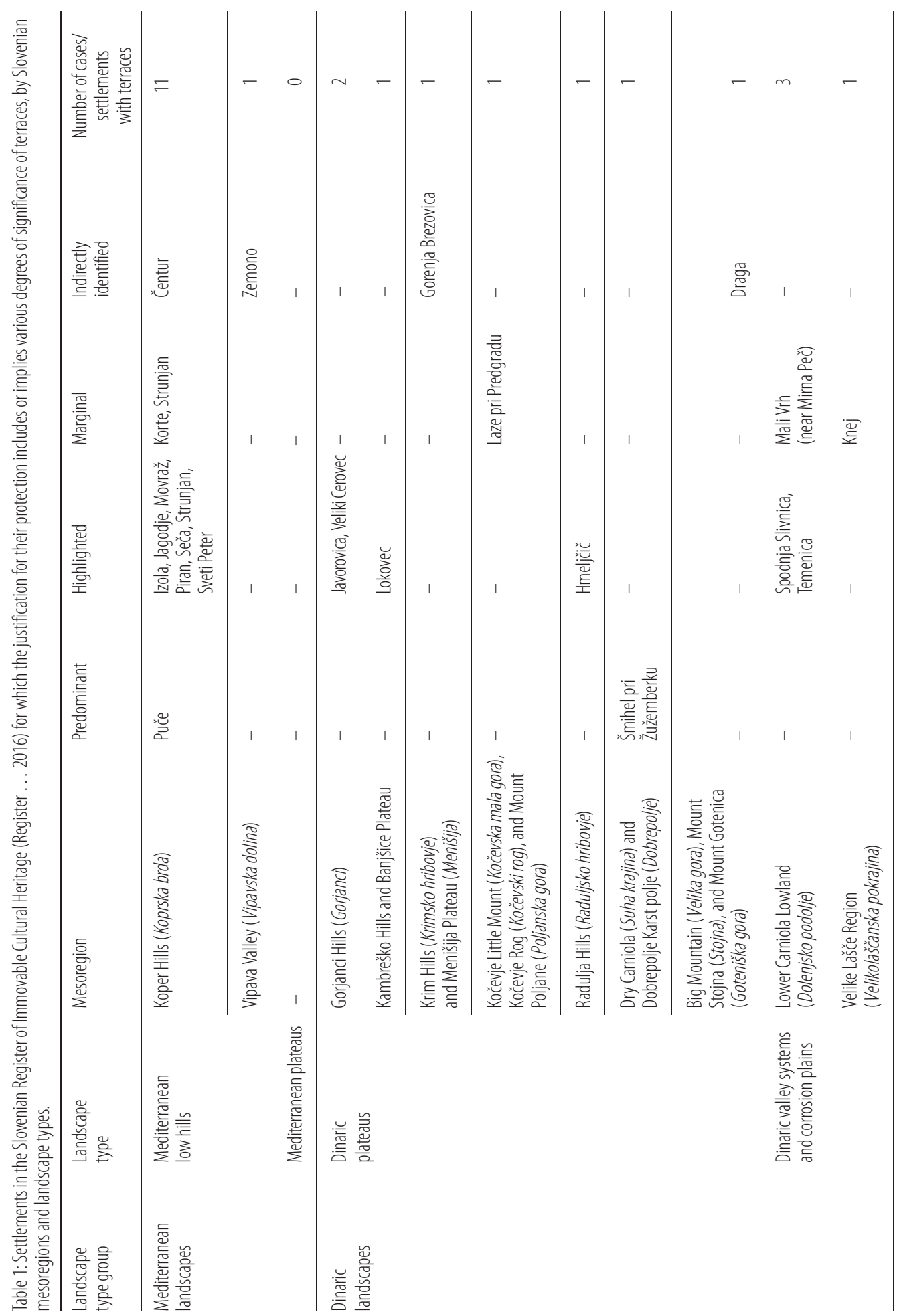




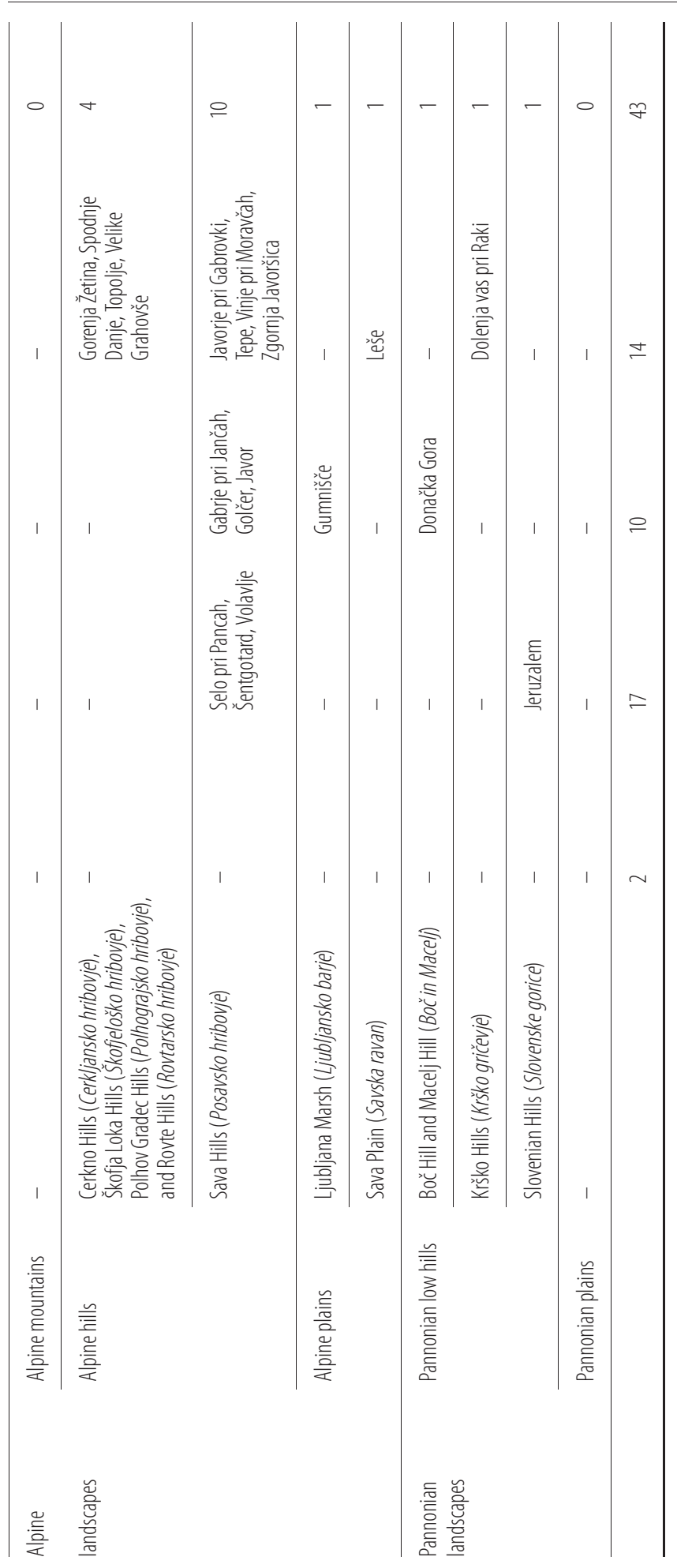




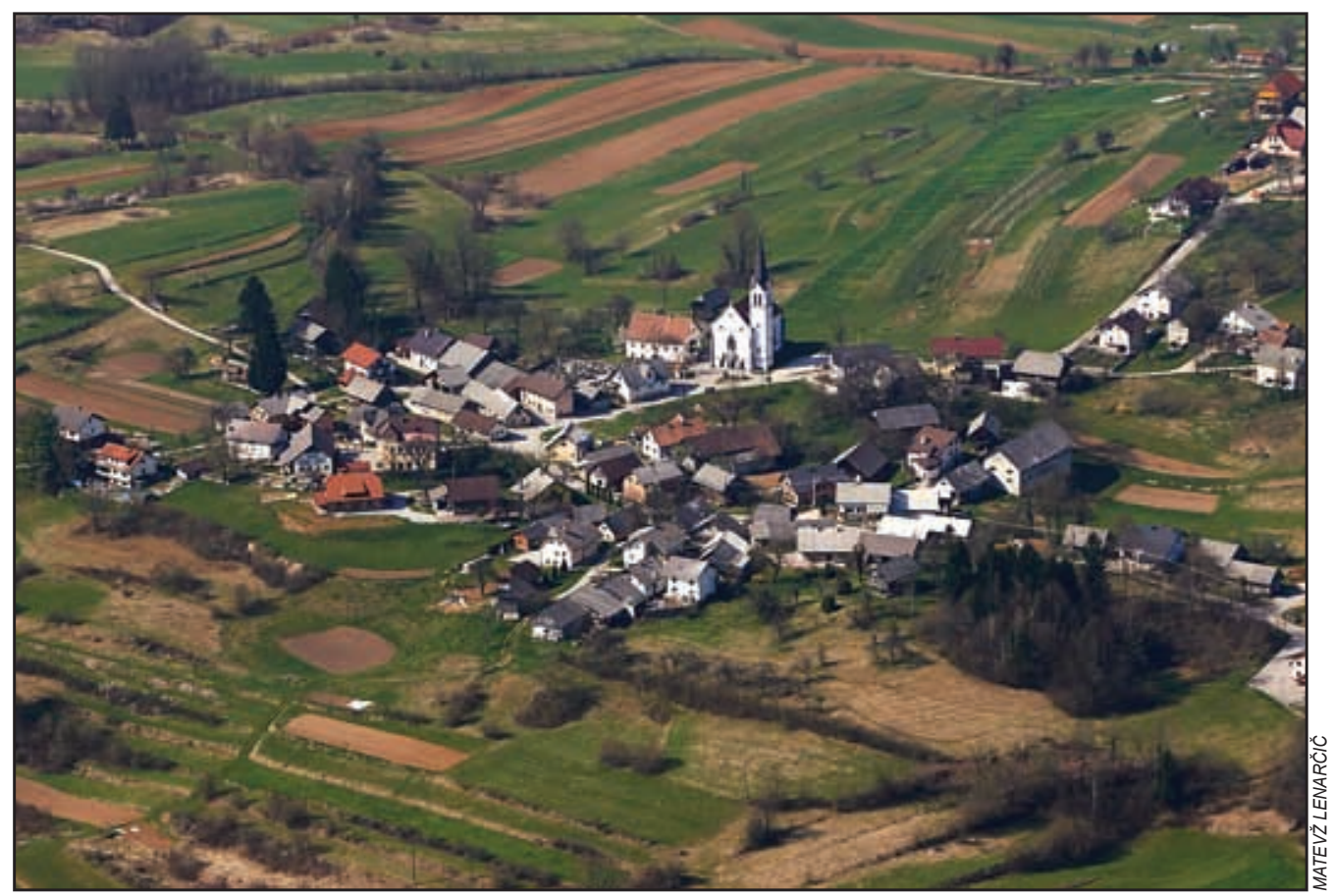

Figure 8: Land surrounding Šmihel pri Žužemberku in Dry Carniola was included in the register precisely because of its well-known terraced landscape.

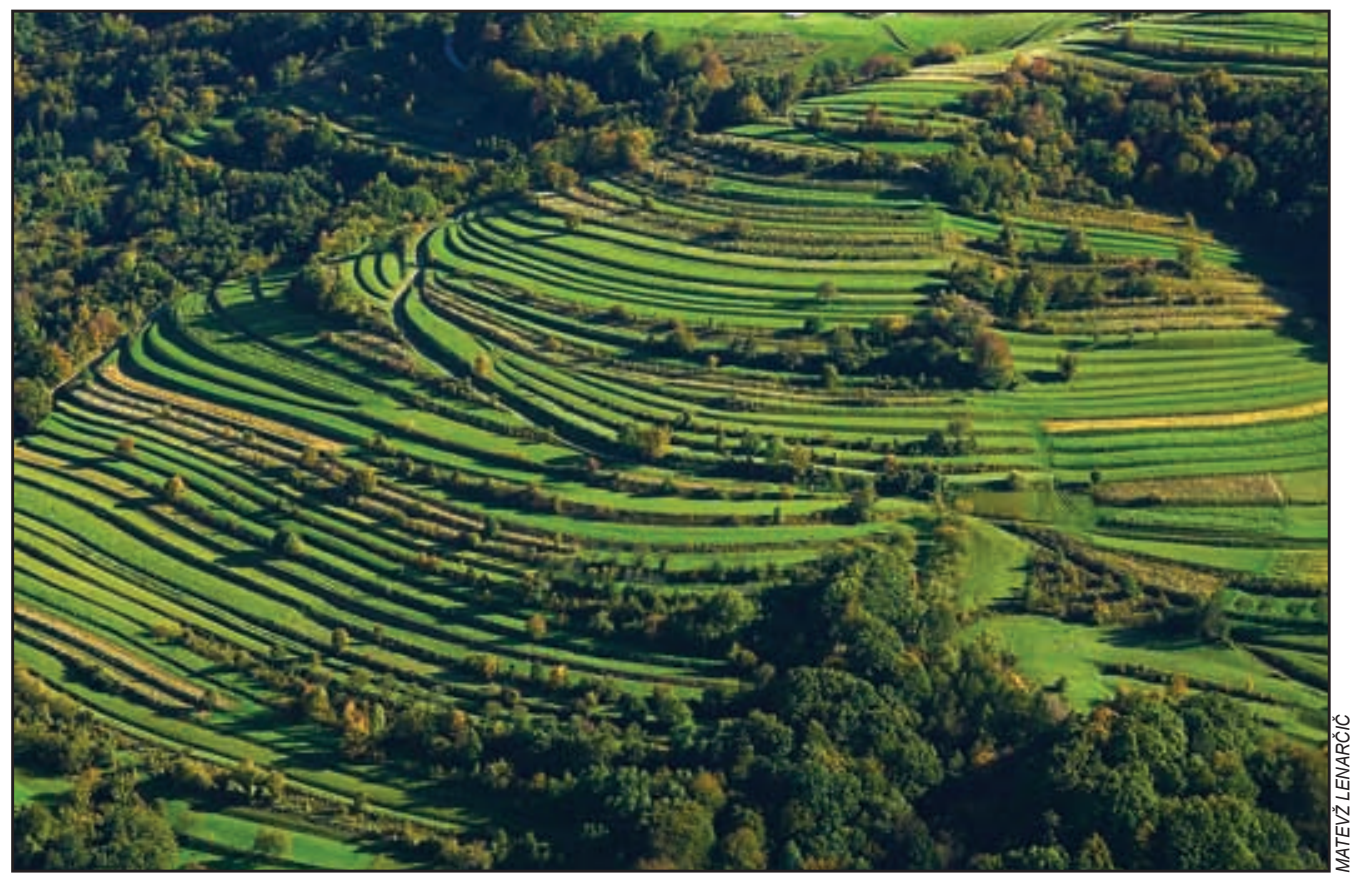

Figure 9: Like all other terraced areas in the Brkini Hills, the land surrounding the village of Ostrožno Brdo has not yet been recognized by conservationists as deserving protection. 


\section{Discussion}

Terraced landscapes account for $22.7 \%$ of cultural landscape sites and $2.4 \%$ of all sites on the UNESCO World Heritage List (2016), for which the listing is legally binding and is considered a great prestige considering that it has established itself as a successful brand (Erhartič 2014). We determined that the significance of terraces in the justifications for entering individual sites on the list is becoming increasingly more highlighted. This may have been contributed to by the 2010 adoption of the Honghe Declaration on the Protection and Development of Terraces (Peters and Junchao 2012), which among other things emphasizes the role and significance of intangible heritage, which comes especially to the fore in Third World countries, where collectiveness in work, free time, and rituals is still an important value.

In the international Satoyama Initiative (2016) database-which has just begun to be compiled and the main point of which is high-quality and systematic descriptions of the sites included, the protection of which is, however, not legally binding-there is a notable predominance of Asian and African landscapes. Terraced landscapes account for $8.8 \%$ of all cultural landscapes described in this database.

We determined that in the »cultural landscape « category of the Slovenian Register of Immovable Cultural Heritage (Register ... 2016), terraces appear as a protection factor only in $13.7 \%$ of cases, and that among the total of 29,893 Slovenian immovable cultural heritage sites terraced landscapes account for only $0.14 \%$. Knowing the actual conditions in the field, it can be arrgued that, despite seemingly suitable coverage of terraced landscapes in Slovenia, the existing range of protected sites included in the register is deficient. In this regard, deficient criteria for the inclusion and the occasionally terminologically deficient descriptions in the justifications for the sites' protection can be established (see, e.g., the description for Jeruzalem, reg. no. 7867; Register ... 2016). This points to a considerable lack of awareness and poor identification of terraced landscapes' values among the responsible experts in the majority of regional units that prepare the protection strategy and plans and the expert bases justifying the inclusion of individual sites in the register.

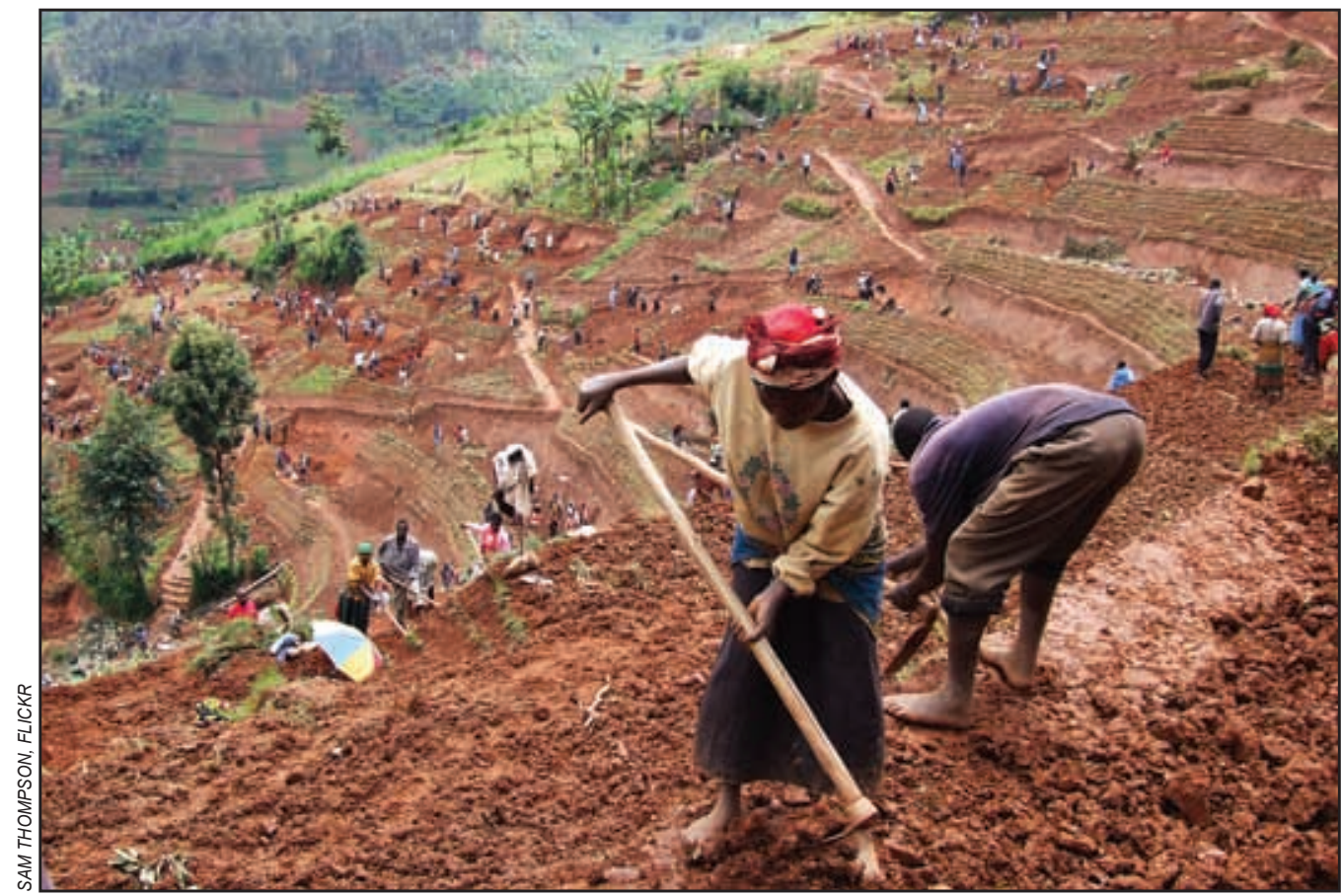

Figure 10: Terracing a slope in Rwanda as part of public works. 
In Slovenia cultural landscapes and terraced landscapes as parts of them have not yet been officially recognized as part of intangible heritage, even though certain practices and skills of cultivating terraced land definitely form part of such heritage (Ažman Momirski et al. 2008). Due to farming organized by families in the areas of Slovenian terraced landscapes, we haven't identified any organization of labor, celebrations, and rituals connected with the cultivation and maintenance of terraces within the wider village community so far.

The Digital Encyclopedia of Slovenian Natural and Cultural Heritage (DEDI, 2016) among the 468 units also includes a description of the terraced landscape in the Upper Gorizia Hills (Zgornja Goriška brda) (Kladnik 2010). Just like any other area in most distinctly terraced Slovenian region of the Gorizia Hills (Goriška brda), the presented site has not yet been officially registered as a cultural heritage site. However, the author believes that considering its significance as a cultural value the site deserves to be protected against the possible deterioration that threatens the demographically endangered northern part of the region.

The review of the world and Slovenian heritage lists raises certain questions: which terraced landscapes are worth protecting and why, is their function or external appearance more important, when did they become heritage, in which cases do they deserve to be protected, and so on. Since only selected sites can be protected it is first necessary to inventory various terraced landscapes and create the criteria for their protection. Here (Table 2) we list a few possible criteria that were identified as part of the project Terraced Landscapes in Slovenia as Cultural Values.

Table 2: Criteria, identified for evaluating of terraced landscapes in Slovenia.

\begin{tabular}{ll}
\hline Criteria & Type of criteria \\
\hline A large contiguous area of terraced land & Spatial \\
The method of terrace construction & Spatial and time related \\
The shape of terrace treads & Spatial \\
The height of terrace slopes & Spatial \\
Time of construction & Time-related \\
Planned construction (whether the terraces were planned or created & Time-related \\
spontaneously with slope processes caused by man) & \\
Rarity & Spatial and time related \\
State of conservation & Legislative \\
Any other accompanying features & - \\
Habitats of endangered plant and animal species & Natural/ecological \\
\hline
\end{tabular}

\section{Conclusion}

Based on the reviews performed, the following findings can be highlighted:

- Terraced landscapes and cultivated terraces began to be classified under heritage sites fairly late, or only after a special category of »cultural landscapes« was established in general;

- Terraced landscapes are a significantly more important element of protection than is evident from the descriptions because those that protected them did not realize the significance of cultivated terraces, and in Slovenia no uniform criteria were in place then, and still are not;

- Intangible aspects of terraced landscapes (e.g., group work, celebrations, rituals, etc.) are already being recognized around the globe, but this does not apply to Slovenia;

- In Slovenia, terraced landscapes could start being regarded as a special subtype of cultural landscape that deserves special treatment due to the complexity of treating it effectively.

The protection of terraced landscapes must definitely be connected with active survival strategies and the farmers for whom work in a terraced landscape represents an important source of food and an important level of subsistence or even market surplus production. To achieve all of this, it is necessary to maintain a vital cultural landscape with a sufficient number of people that are able to work and ready to contribute their share to further maintaining an attractive terraced landscape. If this landscape manages to be added to world protection lists, such as the UNESCO World Heritage List, this provides new tourism-based development prospects, which can generate many new jobs not only in the hospitality sector and accompanying activities, but also in secondary activities on farms. 


\section{References}

11 Incredible Terrace Fields. Internet: http://www.touropia.com/incredible-terrace-fields/ (20.6. 2016).

17 Tremendous Terraced Rice Fields. Internet: http://www.lovethesepics.com/2011/02/17-tremendousterraced-rice-fields/ (20.6.2016).

Amazing satellite images from around the world. Benjamin Grant, Caters News. Internet: http://news.yahoo.com/ photos/amazing-satellite-images-from-around-the-world-slideshow/ (20.6.2016).

Andlar, G., Šrajer, F., Trojanović, A. 2017: Classifying the Mediterranean terraced landscape: The case of Adriatic Croatia. Acta geographica Slovenica 57-2. DOI: http://dx.doi.org/10.3986/AGS.4673

Ažman Momirski, L., Kladnik, D., Komac, B., Petek, F., Repolusk, P., Zorn. M. 2008: Terasirana pokrajina Goriški brd. Geografija Slovenije 17. Ljubljana.

Ažman Momirski, L., Kladnik, D. 2015: The terraced landscape in the Brkini Hills. Acta geographica Slovenica 55-1. DOI: http://dx.doi.org/10.3986/AGS49101

Convention concerning the protection of the world cultural and natural heritage. UNESCO. Paris, 1972. Internet: http://whc.unesco.org/archive/convention-en.pdf (2.4.2016).

Cultural Heritage Protection Act. Official Gazette RS 16/2008, 123/2008, 8/2011, 90/2012, 111/2013, 32/16. Ljubljana.

Cultural Landscapes. UNESCO. Paris. Internet: http://whc.unesco.org/en/culturallandscape/ (2. 4. 2016).

Digital Encyclopedia of Slovenian Natural and Cultural Heritage - DEDI. Internet: http://www.dedi.si (23.6. 2016)

Erhartič, B. 2009: Terase Jeruzalemskih goric kot krajinska vrednota. Pomurje: $20^{\text {th }}$ Congress of Slovenian geographers. Ljutomer, Murska Sobota.

Erhartič, B. 2014: Vloga Unesca pri ohranjanju kulturne dediščine. CAPACities 2. Ljubljana.

European landscape convention. Council of Europe. Internet: http://www.coe.int/en/web/conventions/ full-list/-/conventions/rms/0900001680080621 (23.6.2016)

Geršič, M., Pipan, P., Repolusk, P., Šmid Hribar, M., Tiran, J., Topole, M. 2016: Vzorčni primeri terasiranih pokrajin. Terasirane pokrajine. Ljubljana.

Kladnik, D. 2010: Zgornja Goriška brda. DEDI - digitalna enciklopedija naravne in kulturne dediščine na Slovenskem. Internet: http://www.dedi.si/dediscina/86-zgornja-goriska-brda (23.6.2016).

Kladnik, D. 2016a: Terasirane pokrajine in Honghejska deklaracija. Terasirane pokrajine. Ljubljana.

Kladnik, D. 2016b: Terasirane pokrajine v Sloveniji. Terasirane pokrajine. Ljubljana.

Kobori, H., Primack, R. B. 2003: Participatory Conservation Approaches for Satoyama, the Traditional Forest and Agricultural Landscape of Japan. AMBIO: A Journal of the Human Environment 32- 4. DOI: http://dx.doi.org/10.1579/0044-7447-32.4.307

Komac, B., Zorn, M. 2008: Plazovitost Goriških brd. Terasirana pokrajina Goriških brd. Geografija Slovenije 17. Ljubljana.

Nature Conservation Act. Official Gazette of the Republic of Slovenia 96/2004, 61/2006, 63/2007, 32/2008, 8/2010, 46/14. Ljubljana.

Operational guidelines for the implementation of the World Heritage Convention. UNESCO. Paris. Internet: http://whc.unesco.org/archive/opguide12-en.pdf (20.6.2016).

Paris declaration on the Satoyama Initiative. Internet: http://satoyama-initiative.org/wp/wp-content/uploads/ 2011/09/Paris_Declaration_EN_april2010_revised03_low.pdf (15.5.2016).

Perko, D., Hrvatin M., Ciglič, R. 2015: A methodology for natural landscape typification of Slovenia. Acta geographica Slovenica 55-2. DOI: http://dx.doi.org/10.3986/AGS.1938

Peters, H. 2015: Disappearing terraces: can international tools support safeguarding terraced landscapes and their traditional knowledge?

Peters, A. H., Junchao, S. (eds.) 2012: First terraced landscapes conference (Honghe - China) paper collection. Kunming. II Congreso Internacional de Terrazas: encuentro de culturas y saberes de terrazas del mundo, Cusco, mayo de 2014. Cusco, Lima.

Register of Immovable Cultural Heritage. Ministrstvo za kulturo. Ljubljana. Internet: http://giskd6s.situla.org/giskd/ (1.3.2016).

Satoyama Initiative. Case studies. Internet: http://satoyama-initiative.org (22.3.2016).

Sauer, C. O. 1925: The morphology of landscape. Berkeley. 
Smrekar, A., Polajnar Horvat, K., Erhartič, B. 2016: The beauty of landforms. Acta geographica Slovenica 56-2. DOI: http://dx.doi.org/10.3986/AGS.3039

Špulerová, J., Dobrovodská, M., Štefunková, D., Kenderessy, P., Izsóff, M. 2017: The features of terraced landscapes in Slovakia. Acta geographica Slovenica 57-2. DOI: http://dx.doi.org/10.3986/AGS.4674

Tarolli, P., Preti, F., Romano, N. 2014: Terraced landscapes: From an old best practice to a potential hazard for soil degradation due to land abandonment. Anthropocene 6. DOI: http://dx.doi.org/10.1016/ j.ancene.2014.03.002

Tentative Lists. UNESCO. Paris. Internet: http://whc.unesco.org/en/tentativelists/ (6. 5.2016).

The World Heritage List: filling the gaps - an action plan for the future. ICOMOS - International Council on monuments and sites. Paris. Internet: http://whc.unesco.org/uploads/activities/documents/ activity-590-1.pdf (30.6.2016).

Urbanc, M. 2002: Kulturne pokrajine v Sloveniji. Geografija Slovenije 5. Ljubljana.

Varotto, M. 2015: Terraced landscapes of the Alps: Decay, rediscovery, revitalization. II Congreso Internacional de Terrazas: encuentro de culturas y saberes de terrazas del mundo, Cusco, mayo de 2014. Cusco, Lima.

World Heritage List. UNESCO. Paris. Internet: http://whc.unesco.org/en/list/ (15.4.2016). 